\title{
Implementation of Dayaknese Educational Philosophy Pintar Harati at Elementary School in Palangka Raya
}

\author{
Joni Bungai \\ Faculty of Teacher Training and Education \\ State University of Palangka Raya (UPR) \\ Palangka Raya, Indonesia \\ Jonni.Bungai@fkip.upr.ac.id
}

\author{
Indra Perdana \\ Faculty of Teacher Training and Education \\ State University of Palangka Raya (UPR) \\ Palangka Raya, Indonesia \\ indra.perdana@fkip.upr.ac.id
}

\begin{abstract}
Dayaknese in Central Borneo has an educational philosophy called "Pintar Harati". This philosophy contains the norms and values that govern the lives of the so-called belom bahadat or habitual life. This study aims to describe the implementation Pintar Harati philosophies in School. This study used qualitative research method and analysis with ethnography model from Spradley. Data collected through observation, interview, the study of documents and audio-visual equipment. Results of this study showed (1) planning that incorporates local content into the curriculum and integrates the values of philosophy Pintar Harati into the syllabus and lesson plans. (2) Implementation of philosophy Pintar Harati carried out inside and outside the classroom, through the activities of local content, extracurricular, habituation, assessment of learning and exemplary teachers. (3) The form of the parental role in the implementation of the philosophy form of a) support for learning activities in schools, as well as the actions of factual support; b) planting concept Dayak cultural values at home through habituation and giving examples (role models); and c) Strengthening the role of proactive Dayak Customary Council in synergy with the school.
\end{abstract}

Keywords-Educational Philosophy, Pintar Harati, Dayak, learning at elementary school

\section{INTRODUCTION}

Dayaks tribe of Central Borneo have little evidence in written history, as most of their account is in the form of oral tradition. The Dayak legend is one of the oral languages which can be used to trace the socio-cultural history of the community that produced the legend texts [1].

Dayak tribe in Central Borneo has always had a philosophy of education "Pintar Harati". This life philosophy contains the norms and values that govern the lives of so-called "belom bahadat" or habitual life. In the view of the Dayak tribe in Central Borneo, good human and the ideal is a man who "Pintar Harati". Pintar regard to intelligence or intellectual qualities of a person. Meanwhile, Harati regards to a person of good character. Both of the competence or the ability to interact and complement each other. That is the Pintar but not Harati is not good because with his intelligence could be used to harm others and himself. Harati but not Pintar people are also incomplete because with Harati is not enough to live on today [2].
According to Lickona's character is a person's inner nature responding to the situation morally manifested in concrete action through good behavior, honest, responsible, respectful and respect others and character other noble [3].

One might see the meaning of life as constitutive of the meaning of education, and answers to the question of life's meaning might be seen as justifying (a particular form of) education[4]. Our focus, however, lies in the contributory relation: our primary purpose is to investigate whether and how education might contribute to children's ability to find meaning in life or at least deal with the question [5-8].

Values in Harati can be seen in 4 (four) noble values in the process Though the Think, Though The Heart, Though the Flavor/Intention, and Though the Sports as follows: (a) Thought the Think: intelligent, critical, creative, innovative, curious, thinking open, productive, science and technologyoriented, and reflective; (B) Thought the Heart: honest, faithful and pious, trustworthy, fair, responsible, empathetic, willing to take risks, unyielding, self-sacrificing and patriotic spirit; (C) Though the Flavor/Intention: caring, friendly, polite, neat, comfortable, respectful, tolerant, helpful, mutual cooperation, nationalist, cosmopolitan, put the interests of the public, is proud to use the language and Indonesian products, dynamic, hard work, and work ethic; (D) Though the Sports: tough, clean and healthy, discipline, sportsmanship, reliable, resilient, friendly, cooperative, determinative, competitive, cheerful, and persistent [9], [10].

Word "Harati" in the Dayak language with regard to the attitude, the attitude of positive things or behave intelligently. People who "Harati" those who show interest and attention to the right things useful for themselves and for others. Things are as dangerous as alcohol and stay away from drugs. Intellectual intelligence includes the ability to think up a high level. While word "Pintar" that people who have low-level thinking skills (knowledge, understanding, and application) and high-level thinking (analysis, synthesis, evaluation and predictive).

Harati response to symptoms of people and events around the usual right, so a positive result both for themselves and for others. People who Harati be respectful values that upheld the public and they try to keep values well into hers so she became a formidable personal and pleasure. Furthermore, people Harati it is a self-conscious person. Means to have the right of self-concept about him so as to put himself in a good 
environment. Harati also ordinary people who took pity on him or "masi arep" so it's not overbearing. People who masi arep will lead to high morale [11].

Pintar Harati educational philosophy is the cultural heritage of Central Borneo Dayak very valuable. culture refers to various aspects of life. So culture includes ways to apply, beliefs and attitudes, as well as the result of human activity that is typical for a community or a particular group of people [12]. Ref. [13]. interpreted the culture not just in traditional clothing, cultural festivals, traditional food, dances, carvings and so on with all the variables. Cultural issues is a matter of mindset and mentality of man.

Application of Pintar Harati education philosophy in education is a function of education in relation to culture. This is one way for the younger generation of Central Borneo not to lose track of that as people do not know the culture of Dayak. In addition to forming an identity that cannot be separated roots and develop indigenous Dayak Borneo as cultural identity [9].

Furthermore, the educational philosophy of Pintar Harati is interpreted as the overall life of Dayak Borneo Tengah who knows learned and clever thinking and uphold unity. Dayak people is not enough just smart/intelligent, but also must have the tenacity, toughness, and elements cleverly. Dayak people must have the spirit of Isen Mulang that is tenacity, toughness and achievement orientation. Resilient in the face of a challenge, have a blend of intellectual and emotional intelligence [14].

Based on the above, this study will explore the application of philosophy Pintar Harati and effectiveness in elementary schools in the city of Palangka Raya. The specific purpose of this research is to gain a deep understanding of the application of the educational philosophy of Pintar Harati in learning in Elementary Schools in Palangka Raya city in terms of (1) Application of philosophers Pintar Harati Dayak tribe in lesson planning, (2) Application of philosophers Pintar Harati Dayak tribe in implementation of learning and, 3) involvement of parents / communities in the implementation of Educational Philosophy Pintar Harati.

\section{METHOD}

This study was conducted at the State Elementary School Experiment of Palangka Raya city, using qualitative research methods with ethnographic approach [15], [16]. The reason for choosing the Elementary school is due to 1) the elementary school had implemented programs in subjects Kalteng Harati in the mulok subject; 2) International Standard School/RSBI, 3) The School located in the city of Palangka Raya, making it easier for researchers to examine.

Collecting data in the field from September to December 2016. The main sources of information (primary data) are teachers who teach these classes, the principal, staff of the school, as well as students. Sources of additional information (secondary data sources) are required to complete, the parents of students in the school as well as an education expert from the Palangka Raya University, cultural experts, and stakeholders of Kalteng Harati (Head of Education Department of Central Borneo Province).
Data were collected through observation, interview, the study of documents and audio-visual equipment. Data were analyzed using analysis model Spradley ethnographic data. Analysis of the data directly from the taxonomic analysis, followed by component analysis and thematic analysis. Domain analysis has been carried out because researchers have to have focus and sub-focus of research.

\section{RESULT OF THE RESEARCH}

\section{A. Implementation of philosopher Pintar Harati in Planning Learning}

The learning plan in SDN 1) Experiment provide additional payload into its curriculum which includes the values Harati in the form of (a) The character education, b) anti-corruption education, c) environmental education including peat lands and the ecosystem; 2) Teachers have been integrating the values of the educational philosophy of Pintar Harati in syllabus and lesson plans, although not written explicitly; 3) The learning objectives are written not fully describe the process and the results to be achieved by students and no indicators of learning that contains the values Harati explicitly; 4) Plan of ratings not comprehensively assess aspects of Pintar Harati (cognitive, affective and psychomotor) and do not have a complete instrument and rubrics to assess three aspects.

Development of Pintar Harati values, in each subject, can be done by integrating the values of character education into the Basic Competency (KD) contained in the Content Standards. Total KD every subject that can be integrated values of character education is different, there are more and some less. Further core competencies which can be integrated values of character education were developed in the syllabus and lesson plans.

Furthermore, teachers set goals and indicators of learning explicitly load values Pintar Harati. Indicator compiled learning has accommodated the cognitive level of $\mathrm{C} 1-\mathrm{C} 3$, and psychomotor. On the other hand, teachers prepare a lesson plan that provides learning experiences to learners. Although the planned learning experience is still not maximized because not many planned to learn activities based on a scientific approach [9].

In the document syllabus and lesson plans (RPP), teachers have planned a variety of assessments in accordance with assessment standards. Assessment is carried out in the form of written and unwritten, by entering Pintar harati aspects in a comprehensive and sustainable.

\section{B. Implementation philosophy of Pintar Harati in learning.}

The implementation of philosophy Pintar Harati can be seen in teaching and learning process at school.

1) Teaching and Learning in the Inside and Outside the Classroom.

Implementation of learning inside and outside the classroom: 1) Implement Dayak cultural values such as Balinga, Menteng Ureh, Pantan, Pahewan and Isen Mulang; 2) Local wisdom taught in the mulok subject in SDN Experiment include: Language and Literature Dayak, Dayak Traditional 
Sports, Arts, traditional 'cuisine, as well as the natural environment and ecosystem. References in the school subjects very limited mulok lesson and training teachers of mulok still rare; 3 ) The value used in the conditioning/civilizing explicitly in the form of Dayak cultural values.

\section{2) Learning Muatan Lokal Subject (Mulok).}

As mentioned in GBPP Mulok Central Borneo that local content is very important because it is through Muatan Lokal will develop students' potentials to be local people who understand, know and care about the situation and the problems around, grow and develop in accordance with its identity and local culture and Central Borneo Dayak educational philosophy "Pintar Harati":, which also became an Indonesian citizen and a citizen of the world of good and responsible [2].

\section{3) Habituation /civilizing.}

In general, habituation/familiarization in SDN Experiment in 3 activities. Habituation/familiarization include routines, spontaneous activities, and conditioning. Routine activities are activities that do learners continually and consistently every time. For example, the ceremony Monday, a large ceremonial state, class picket, march when coming to class, praying before class begins and ends, and say "hello" when meeting teachers, educators, and friends. Spontaneous activity is an activity that students spontaneously at that time. For example, collect donations when there are friends in the affected areas, contribute to the community when a disaster, etc. Furthermore, the conditioning is the creation of conditions that favor fulfilled character education. E.g clean toilet conditions, the availability of trash can, green courtyard with trees, posters wise words on display in the halls and in the classroom, etc.

\section{4) Extracurricular Activities.}

Findings of the research show that SDN experiment was able to develop a variety of extracurricular activities. Extracurricular activities is one way to instill the values of Dayak culture in the context of the implementation of the educational philosophy of Pintar Harati, like menteng ureh (bold and unyielding), barendeng (perceptive and alert), Balinga (pretty, clean, neat), masi arep (love self / respect yourself), and isen Mulang (toughness and orientation on achievements) [11].

\section{5) Assessment of Learning.}

Assessment aims to monitor the process and progress of learners and to improve the effectiveness of the learning activities. Valuation has several benefits. The assessment was conducted to determine student competency achievement. Ratings provide feedback on students' progress. Besides the assessment also helps the teacher to make decisions about the needs of students, and program planning future learning. Therefore, the assessment should be an integral part of the learning program.

Furthermore, students' progress reports are a reflection of student competence achievement, so it must be able to provide a complete picture, a complete and comprehensive about achieving Pintar aspects (cognitive and psychomotor) and aspects Harati (attitudes) students. Students' progress reports should be able to describe not only Pintar but also Harati of grades students. Harati becomes very important aspect to be developed and evaluated, considering the attitudes of elementary school age aspect is a top priority for being taught in school.

\section{6) Exemplary Teacher}

Exemplary is the behavior and attitudes of teachers and education personnel in giving an example through good actions that are expected to become a role model for students. Exemplary be one very effective way of instilling the values of the philosophy Pintar Tuntang Harati, because teachers act as models for the students.

\section{Parental Involvement Student Parents in application of Philosophy Pintar Harati}

Parents of students whose background Dayak in these schools still has the awareness to take part in preserving the cultural values Dayak. But their role cannot be said to be optimal and structured. This shows that as the Dayak still have etiko quintessential mythic culture[13].

Furthermore, based on interviews with selected informants namely Dayak cultural experts like Lewis KDR, Sabran Ahmad, and Sidiq R. Usop, stated that the people of Central Borneo quite active and proactive role in implementing Dayak cultural values to create a man who Pintar Harati. Some of the roles that need to be strengthened are: a) Parents should set an example (role model) in implementing Dayak cultural values; b) The existence of a system developed to preserve the cultural values Dayak; c) Strengthening the role of Central BorneoBorneo Dayak Customary Council and experts/ specialists Dayak culture, as well as proactive costmaries figures synergy with formal educational institutions [14].

In addition, the support of parents towards learning activities in schools, in the form of actual actions to support the school to realize student pintar harati quite optimal. Planting concept Dayak cultural values at home through habituation/ factual activity by parents whose background Dayak Tribe.

\section{DISCUSSION}

Schools are institutions in society to educate children. Schools are also expected to contribute the moral education to children, by having lessons in good manners [17]. Students must be given an opportunity to make a choice of value freely. The student should be encouraged to predict and to consider the possible consequences of alternative values. They should be helped to clarify conflicts and confused values [18]. In this case, the school becomes strategic areas to develop the ethical, moral. It can be achieved through the education which based on the local cultural development.

Lesson planning activities by drafting Learning Implementation Plan (RPP) in accordance with national standards, by integrating cultural values Dayak. Cultural values Dayak used are cultural values which are still alive and thriving in everyday life, have idea/ideas as a source of knowledge related to character education, guidance human interaction with humans, humans with nature, and the relationship with the creator and have a tangible manifestation in daily life through the implementation of the ceremonies.

In addition, RPP compiled by the teacher write the objectives and measurable indicators, describing the plan 
learning activities that can provide meaningful learning experiences for the development of physical and psychic, explicitly load the values of Pintar Harati through interactions with a variety of learning resources contextual including ICT and using models and teaching methods with a scientific approach.

Implementation of the learning is done to encourage the formation of intelligent and creative students, the implementation of learning includes: 1) creating a classroom atmosphere pleasant manner chairs table setting, the display, and the students' work, as well as the arrangement of resources and learning aids; 2) using the environment as a learning resource, such as physical and social environment, and events; 3) Implement models of active learning and contextual with a scientific approach.

Learning assessment conducted to measure the overall aspects of Pintar Harati (cognitive, affective, and psychomotor) with authentic assessment techniques. The goal is to measure learning outcomes (output) and processes. Authentic assessment includes test and non-test. The test consisted of (a) Written test: Shape objective (multiple choice, stuffing) and description; (B) oral test; and (c) Test Acts: Performance (Performance), Assignment (Project), Works (Product). Meanwhile Non-Observation Attitudes Test form, Portfolio, Journal.

Further to written questions, the teacher should provide questions to measure the high-level thinking skills (analysis, evaluation, creation), in addition to measuring the ability of low- and middle-level thinking. In addition to developing creativity and thinking ability to train high-level, also provides questions whose answers are not single, as well as appreciate the answer eccentric.

The various parties have given positive support, in the form of policy or regulation (the government), in the form of moral and material support (the school committee, the community, the non-governmental organizations), as well as the commitment of the school to equip the students in the form of knowledge, attitudes, and skills optimally in accordance with the vision, mission, and the objectives of the school. It is related to the research results by [19], [20], [21] about some factors that can support and hinder the implementation of the local content at the schools

Third, the role of the parents/society. Parents/society must play an active role in implementing the educational philosophy of Pintar Tuntang Harati. Therefore, schools must seek to encourage the active involvement of parents in school activities. This effort must be made through an intensive communication with parents, involving parents as sponsors/organizers in school activities, decision making, and support the success of student learning.

Shape the role of parents/community in the implementation of the philosophy Pintar Tuntang Harati is either: a) support for learning activities in schools, in the form of factual actions to support schools student, realize Pintar Tuntang Harati; b) the concept of planting efforts Dayak cultural values at home through habituation/factual activity and giving examples (role models); and c) Strengthening the role of Central Borneo
Dayak Customary Council and experts/specialists Dayak culture, as well as traditional leaders to be proactive in synergy with formal educational institutions.

\section{CONCLUSION}

- Philosophy of education "Pintar Harati" contains the norms and values that govern the lives of so-called "belom bahadat"or habitual life. The implementation in elementary school can be done in the learning process. Pintar Harati educational philosophies in learning plan implemented by: 1) Provide additional local content into the curriculum which includes the Pintar Harati values in the form of (a) The character education, b) anti-corruption education, c) environmental education including peatlands and the ecosystem; 2) Teachers integrate the values of the educational philosophy of Pintar Harati in the syllabus and lesson plans. 3) The learning objectives are written describing the process and the results achieved by the students, by loading the values Harati explicitly; 4) Plan implicitly ratings insert aspect Pintar Harati (cognitive, affective and psychomotor).

- Implementation of the educational philosophy of Pintar Harati in the implementation of learning, held inside and outside the classroom, namely: 1) implement a Dayak cultural values Balinga, Menteng Ureh, Pantan, Pahewan and Isen Mulang; 2) Local wisdom taught in the lesson of mulok include: Language and Literature Dayak, Dayak Traditional Sports, Arts, traditional 'cuisine, as well as the natural environment and ecosystem. 3) The value used in the conditioning / civilizing explicitly in the form of Dayak cultural values, such as the concept of the value of a) Huma Betang; b) Handep; c) Masi Arep; d) Menteng Ureh; e) Balinga; f) Pamasi; g) Barendeng; h) Marega uluh Bakas, i) Utus; j) Belum Bahadat; k) Manakir Petak.

- The role of parents/community in implementation of the philosophy pintar harati are: a) support for learning activities in schools, in the form of actual actions to support schools student realize Pintar Tuntang Harati; b) the concept of planting efforts Dayak cultural values at home through habituation/ actual activity and giving examples (role models); and c) Strengthening the role of Central Borneo Dayak Customary Council and experts/specialists Dayak culture, as well as traditional leaders to be proactive in synergy with formal educational institutions.

\section{REFERENCES}

[1] M. A. Luardini, "Socio-Cultural Values of Traditional Communities: A Case Study of the Dayak in Kalimantan," Asian Cult. Hist., vol. 8, no. 2, hal. 1, 2016.

[2] B. Garang, "Pintar harati (Filsafat Pendidikan Orang Dayak)," Kalteng Pos, Palangka Raya, hal. 4, 2007.

[3] T. Lickona, Educating Character: How Our Schools Can Teach Respect and Responsibility. New York: Bantam Book, 1992.

[4] G. L. Gutek, Philosophical Alternatives In Education. Ohio: Charles E. Merrill Publishing Company, 1994. 
[5] G. J. S. Dei, "African Indigenous proverbs and the institutional and pedagogic relevance for youth education: Lessons from Kiembu of Kenya and Igbo of Nigeria," J. Educ. Train., vol. 59, no. 3, hal. 344362, 2013.

[6] B. A. Adeyemi, "The Place of Indigenous Proverbs in Peace Education in Nigeria: Implications for Social Studies Curriculum," vol. 4, no. 2, hal. 186-192, 2014.

[7] J. J. M. \& E. G.-O. Larry W. Owens, “Activating a Teaching Philosophy in Social Work Education: Articulation, Implementation, and Evaluation," J. Teach. Soc. Work, vol. 34, no. 3, hal. 332-345, 2014.

[8] A. Schinkel, A., De Ruyter, D. J. And Aviram, "Education and Life's Meaning," J. Philos. Educ., vol. 50, no. 3, hal. 398-418, 2016.

[9] D. P. K. Tengah, Naskah Akademik Kalteng Harati. Palangka Raya, 2010.

[10] R. Mungmachon, "Knowledge and Local Wisdom : Community Treasure Miss Roikhwanphut Mungmachon Ph.D. Candidate in Integral Development Studies," vol. 2, no. 13, hal. 174-181, 2012.

[11] K. Sulang, Masi Arep Ah Sebagai Filosofi, Budaya Dayak: Permasalahan dan Alternatifnya". Malang: Bayu Media, 2011.

[12] T. O. Ihromi, Pokok-Pokok Antropologi Kebudayaan. Jakarta: Gramedia, 1994.
[13] K. Tarung, Mengenal Orang Lain, Bangun Komunikasi (Untai Pendapat: Di mana Bumi di Pijak Di Sana Langit Di Bangun, Transformasi Sosial Pembebasan Melalui Re-Humanisasi). Malang: Bayu Media, 2011.

[14] J. Kusni, Dayak Membangun: Kasus Dayak Kalimantan Tengah. Jakarta: Jakarta Paragon, 1994.

[15] J. P. Spradley, Metode Ethnografi, (terjemahan). Yogyakarta: Tiara Wacana, 2007.

[16] P. Hammersley. Martyn \& Atkinson, Ethnography Principles In Practice. New York: Routledge, 1983.

[17] J. G. \& C. Winch, Philosophy of Education: The Key Concepts. Routledge, 2008.

[18] J. A. Banks, "Race, Culture, and Education."

[19] Margilestanti, "Implementasi Pendidikan Berbasis Keunggulan Lokal Implementation Of Education Based On Local Excellence In Sd,” p. 201-209.

[20] N. Hindaryatiningsih et al., "Implementation of Local Cultural Value in Character Education Program Supervision," vol. 7, no. 3, p. 91-97, 2017.

[21] Fatimah, "Pengembangan pendidikan karakter dan keunggulan lokal dalam kurikulum kejuruan di smk negeri kabupaten tapin,” vol. 6, 2016. 